\title{
„Üdv a fedélzeten” - A Budapesti Gazdasági Egyetem oktatói mentorprogramja
}

\section{Dósa Katalin' - Tóth Katalin²-Sebestyén Lilla Anna}

\author{
${ }^{1}$ Budapesti Gazdasági Egyetem, Oktatásmódszertani Központ vezetője \\ dosa.katalin@uni-bge.hu \\ ${ }^{2}$ Budapesti Gazdasági Egyetem, Oktatásmódszertani Központ, ügyvivő szakértője \\ toth.katalin@uni-bge.hu \\ ${ }^{3}$ Budapesti Gazdasági Egyetem, Oktatásmódszertani Központ, ügyvivő szakértője \\ sebestyen.lilla@uni-bge.hu
}

A felsőoktatásban megjelenó változásokra reagálva a Budapesti Gazdasági Egyetemen létrehoztunk egy, a belépő oktatók számára kialakított programot, amelyben mentoráltszakmai mentor-oktatásfejlesztő triádok dolgoznak együtt egy teljes féléven át. Az Üdv a fedélzeten elnevezésú program kerete az EPIC-modellre, az oktatói fejlódési modellre és a mentorálási szakirodalomra épít, elemei pedig nemzetközi gyakorlati példák helyi kontextusba való átültetésével kerültek kialakításra. A program háttere, szerkezete és eddigi tapasztalataink bemutatása után megfogalmazunk a magyar felsőoktatás számára megfontolandó tanulságokat, kijelölünk fontos kihívásokat, és kitérünk jövőbeni terveinkre is.

Kulcsszavak: felsőoktatás, mentorálás, SGID, oktatásfejlesztés, szocializáció

DOI: 10.37205/TEL-hun.2020.1-2.03

Napjainkban a felsőoktatás eredményessége jórészt azon múlik, hogy elismert, motivált, kiváló szakmai kvalitású oktatói, kutatói és az oktatást közvetlenül segítő dolgozói vannak-e. Ebből kifolyólag az egyetemi oktatók támogatása és módszertani fejlesztése kiemelten fontos terület, hiszen csak megfelelő szakmai és módszertani felkészültség birtokában várható tőlük, hogy intenzívvé tegyék a tanulást hallgatóik számára, ezzel közvetlenül is meghatározva az oktatás minőségét. Az oktatók fejlesztésének egyik lényegi pontja a belépő oktatók friss, hallgatóközpontú pedagógiai módszerekre történő szocializációja. Ennek megvalósításához a Budapesti Gazdasági Egyetemen létrehoztunk egy új, nemzetközi modellekre építő mentorálási rendszert belépő oktatóinknak, melynek során oktatásfejlesztőink szakmai mentorokkal karöltve kísérik végig belépő oktatóinkat az első tanítási félévükön. 


\section{Miért kell mentorálni?}

A mentorálás gyökerei több ezer évre nyúlnak vissza az emberiség történelmében, amit számos írásos emlék is bizonyít. A mentor mint kifejezés már Homérosz Odüsszeiájában is feltűnik, ahol a föszereplő gyermekét egy „mentor” (Mentór) védelmére bízza. A tudomány és a művészetek területén számos mentorral és mentorálttal találkozhatunk: Szókratész és Platón, Nagy Sándor és Arisztotelész, Leonardo és Verocchio, Haydn és Beethoven, Freud és Jung és még sorolhatnánk.

Ma már a mentorálás minden területen fontos támogatási forma. Braun szerint ennek többek között az az oka, hogy a fiatalok egyre inkább igénylik a szuverenitást, ezért a problémák feldolgozásának hatékony módja a személyes segítségnyújtás lett (Braun, 2008).

A mentorálás fogalmát sokan sokféleképpen definiálták: Kram például a mentorálást olyan tevékenységek készletének tekintette, amelybe beletartozik a tanítás, a pártfogás, a támogatás, és amelyeket egy magas szintű vezető nyújt a mentoráltjai számára. Véleménye szerint a mentor a karriertámogatáson túl a pszichoszociális fejlődésben is szerepet vállal (Kram, 1985). Russel és Adams (1997) leírása alapján a mentorálás egy, az erős személyek között lezajló cserefolyamat, amely egy szenior, tapasztalt kolléga és egy junior munkatárs között megy végbe. Bell (2002) szerint a mentor tanító, vezető, akinek segítségével a mentorált képességeit és tudását minél szélesebben kiterjesztheti és fejlesztheti. Hobson úgy gondolta, hogy a mentori tevékenység „tapasztalt gyakorló tanár által nyújtott egyéni támogatási forma a kezdő vagy kevésbé gyakorlott tanár számára, amelynek elsődleges célja, hogy támogassa a mentorált tanár szakmai fejlődését, illetve gördülékenyebbé tegye a szakma kultúrájába, illetve a speciális helyi kontextus(ok)ba való beilleszkedést." (Hobson et al., 2009).

Az elmúlt 20 évben a mentorálás az oktatás területén is egyre szélesebb körben terjedt el. A közoktatásban szabályozott és támogatott rendszer keretében találkozhatunk hátrányos helyzetű vagy tehetséges tanulók mentorálásával, illetve pályakezdő tanárok kollegiális mentorálásával is. A felsőoktatásban eddig leginkább a hallgatók tehetséggondozása mellett a pedagógusképzésben részt vevő hallgatók mentorálása jelent meg.

A felsőoktatást érintő változások mára elengedhetetlenné tették a tanulási folyamat támogatásának tudatosabb tervezését, a módszertani megújulást az oktatók esetében is. Épp úgy, ahogy a pedagóguspályán, a szakmai tanulás az alapja a módszertanilag felkészültségnek. A kezdő oktató tele van kétellyel, ismerkedik az 
új szereppel, a hallgatókkal, a kollégákkal. Nehezíti ezt a helyzetet a sokszor kimondatlan, de mégis általánosan elfogadott közhiedelem, hogy egy egyetemi oktatónak az a legfontosabb tulajdonsága, hogy jó kutató és jó szakember legyen, tanítani meg úgyis mindenki tud. Az egyetemen viszont központi fontosságúvá válik a szakma múvelése helyett a szakma tanitása, ami a legtöbb belépő oktató számára új terület. Ennek megfelelően a legtöbb belépő oktató nagy kihívásokkal találja szembe magát: az első tanítási éveket leíró szakasz találóan a túlélés elnevezést kapta (Katz, 1972, Fessler, 1991). Ezt az időszakot a káosz, a kapkodás és a kétségek jellemzik, atekintetben, hogy az oktató meg tud-e a felelni a feladatnak, a hallgatóinak és a kollégáinak. Tapasztalataink szerint ma hazánkban az oktatói pálya kezdeti nehézségeihez az ifjú kollégák esetlegesen kapnak csak segítséget szervezett segítséget pedig jellemzően egyáltalán nem, pedig Katz (1972) kiemeli, hogy ebben a fejlődési szakaszban az oktatónak szüksége van folyamatos támogatásra, biztatásra és módszertani, oktatásszervezési tanácsokra olyan mentoroktól, akik a kurzusát és az intézeti kontextust is jól ismerik.

\section{Miért kell most mentorálni?}

Ma Magyarországon négy jelenség együttállása teszi elengedhetetlenül szükségessé a belépő oktatók módszeres támogatását: az oktatói korfa tudatos alakítása, a hallgatói generációváltás, a felsőoktatás tömegesedése és az oktatási paradigmaváltás.

Az oktatói munkaerőpiac sajnos kevéssé mobil, és ezen belül az életpályák is elég egyirányúak. A legfőbb utánpótlást a fiatal pályakezdők ( $\mathrm{PhD}$ hallgatók) jelentik. Ezek a fiatalok néhány év alatt vagy „beválnak”, vagyis megtalálják a helyüket az egyetemen, és maradnak, vagy elmennek. A már komolyabb tapasztalattal rendelkező oktatók egy részét később „elcsábítja” a versenyszféra vagy egy (külföldi) egyetem, kutatóhely. A befelé áramlás - sajnos - ebben a korosztályban már nem nagyon jellemző, inkább csak vendégoktatói vagy óraadói funkcióban.

A fentiek alapján kulcsfontosságúvá válik tehát az oktatói utánpótlás: a felsőoktatásba belépő fiatal kollégák támogatása. Érdemes abba befektetni, hogy sikeresen integrálódjanak, jól érezzék magukat az oktatói pályán a pályakezdők, és ne váljanak pályaelhagyóvá néhány év után. A munkaerőpiacon oktatók szaktudása lényegesen jobban megfizetett, ezért olyasvalamit kell nyújtani nekik a felsőoktatásban is, ami miatt a korlátozott bérek ellenére maradni szeretnének az egyete- 
men. Ilyen lehet az a siker- vagy flow-élmény, amit egy oktató a tanítás és a hallgatókkal való együttműködés során átélhet (Kálmán, 2019).

Az utóbbi években azért is jelentkezik fokozottan a felsőoktatásban a fejlesztés szükségessége, mert a mai hallgatóknak markánsan mások az igényei a tanulás szempontjából, mint a megelőző évfolyamoknak (Seemiller \& Grace, 2016). A hallgatók többsége (BGE-n 70\%) dolgozik (Balázsiné Farkas, 2017), így időgazdálkodásuk megváltozott. Mindezek miatt azoknak az óráknak a látogatottsága, ahol száraz, monoton előadást kell hallgatni mindennemű illusztráció, változatosság vagy interakció nélkül, komoly veszélyben forog.

A hallgatói igények megváltozása mellett a felsőoktatás tömegesedése is új feladatokat jelent az oktatóknak. Amíg az egyetemi képzésben való részvétel csak az érettségiző diákok legkiválóbbjainak privilégiuma volt, addig kevésbé volt érezhető az egyetemi oktatók pedagógiai előképzettségének hiánya a hallgatók tanulási eredményeiben: ezek a diákok ugyanis általában rendelkeztek olyan önálló metakogníciós és tanulási képességekkel, amelyek átsegítették őket a tanulási nehézségeken vagy a tanulás támogatásának hiányán is. Most azonban, amikor a felsőoktatásban sokkal szélesebb körből merítünk, már sok olyan hallgató van akik több segítséget igényelnek, vagy épp más tanulási úton tudnának elérni a kívánt eredményhez. A helyzetet tovább nehezíti, hogy a tömegesedés miatt egyre nagyobb létszámú csoportokat kell szervezni az egyetemeken. Módszertani váltás nélkül ezek a hallgatók akár le is morzsolódhatnak, ami természetesen sem az egyetemnek, sem az oktatónak, sem a hallgatónak nem jó.

Módszertani megújulást sürget az oktatásban párhuzamosan megjelenő paradigmaváltás is, ahol a tanárközpontú oktatástól a tanulóközpontú oktatás felé mozdulnak el a felsőoktatási intézmények (Huba \& Freed, 2000). A tanulóközpontú megközelítést az oktatók és hallgatók közötti kis hatalmi távolság, a felelősség és a hatalom megosztása, a hallgató igényeinek, egyéni érdeklődésének és tehetségének figyelembevétele, a hallgató partnerként kezelése jellemzi. Az ilyen szemléletű képzések, s órák filozófiájukban és megvalósításukban is különböznek az oktatóközpontúaktól: az oktató itt tipikusan nem a tudás egyedüli forrása, sokkal inkább támaszkodik a hallgatók saját ismereteire, véleményére és képességeire, gyakran alkalmaz csoportmunkát, interaktív módszereket, lehetővé teszi a vitát stb. A ma felsőoktatásba lépő oktatók viszont még nem ebben szocializálódtak: legtöbbjük klasszikus, végtelen diasoros előadásokra járt hallgatóként, ahol az egyes előadások sorra vették a tankönyv fejezeteit, a félévet pedig vizsga zárta. 
A Budapesti Gazdasági Egyetemen éppen ezért indítottunk felmenő rendszerben a belépő oktatóknak egy olyan programot, amelyben aktívan integráljuk őket az oktatói közösségbe, követjük és támogatjuk a fejlődésüket.

\section{Miért éppen belépő oktatókat kell mentorálni?}

Fontos szempont az oktatók kiválasztásakor, hogy gyakorló szakemberektől sajátíthassák el a hallgatók a szakma fortélyait (Hénard \& Rosevare, 2012). Alkalmazott tudományok egyetemeként nekünk ez a szempont különösen fontos, belépő oktatóink többsége a saját szakterületén elismert szakember, aki jól ismeri a szakma újításait, eszközeit, sokuk rendelkezik vezetői képességekkel is. A tanítás azonban új terep számukra, éppen ezért van szükségük felkészítésre.

Az oktatók szakmai fejlődése két területen is zajlik. Egyrészt az oktatói szerephez kapcsolódóan, ami magához a tanítási folyamathoz és annak módszertani vetületéhez tartozik. Másrészt pedig az oktatói státuszhoz kötődően kutató, fejlesztő vagy tanácsadó szerepkörökben is megjelenhetnek (Kálmán, 2019).

A pályakezdő oktatók nézetei és ebből is következő módszerei tanításuk megkezdésekor - hisz vannak prekoncepcióik arról, hogy hogyan kell jól tanítani még nagymértékben formálhatók (Füzi \& Suplicz, 2016). A belépéstől számított első három évben még sokkal inkább kísérleteznek új dolgokkal, illetve figyelnek a tapasztaltabbakra. Ez a kezdeti időszak általában érzelmileg intenzív, és szakmai kihívásokban gazdag. Ha ebben a stádiumban fektetünk be időt és törődést, és adunk a belépő oktató mellé pedagógiailag képzett, tapasztalattal rendelkező mentorokat és oktatásfejlesztőket, akkor jó eséllyel formálhatjuk a belépő kolléga szemléletét úgy, hogy az megfeleljen azoknak a szempontoknak, amelyeket a szakma ma a legjobbaknak gondol. A mentorálási élmény továbbá biztonságot nyújt, és fejleszti a reflektív gondolkodást, aminek kialakítása hosszú távon is kulcsfontosságú lesz a szakmai fejlődésben.

Ez a megközelítés számos helyen megjelenik a nemzetközi térben az oktatási intézményekben, egyre több egyetem kínál valamiféle tanítási tréninget, fejlődési lehetőséget belépő oktatóinak. Ezek a programok rendkívül széles skálán mozognak: a holland felsőoktatásban például kötelező pedagógiai kiegészítő diplomát szerezni minden oktatónak (VSNU, 2018), a University of Copenhagen dán egyetemen is mentorálják a belépő oktatókat (CBS, 2018), számos amerikai egyetemen van félév eleji néhány napos tréning, de akár többféléves ösztöndíj program is, 
vagy felkínálják a tanulási közösségekhez való csatlakozást (Yonge \& Davidson, 2017).

A fentiek ismeretében egy olyan, együttműködésen és kölcsönös fejlesztésen alapuló mentorprogramot hoztunk létre, ahol a szakmai és a pszichoszociális fejlődési lehetőség mind a mentorált, mind pedig a mentor számára adott. A felsőoktatás speciális helyzetéből adódóan - kevés a pedagógiai végzettségű, de sok a gyakorló szakemberként dolgozó oktató - fontos szempont volt számunkra, hogy az „egymástól tanulás és közös fejlődés” legyen a programunk alappillére. Ezt úgy valósítottuk meg, hogy a mentorált és a szakmai mentor munkáját egy oktatásmódszertani mentor is támogatja. Így az interperszonális kapcsolat létrejöttén túl kialakul egy olyan fejlesztő háromszög, amelyben egyszerre használjuk ki a tradicionális és a fordított mentorálás előnyeit, ahol mindenki tanulhat mindenkitől. Nemcsak a kölcsönös tisztelet fejlesztéséhez adottak a feltételek, hanem ahhoz is, hogy a mentoráltnak egy szerepmodell másolása helyett olyan önálló, a személyiségéhez illő mentorálási modellt alakítsunk ki, amelyben a leghatékonyabban tudja oot támogatni a szakmai mentor és a módszertani fejlesztő együttese. Ehhez szükséges, hogy a mentorált a „jó mentorált” jellemzőivel (Nagy, 2011), és a mentor a mentoráláshoz szükséges kompetenciákkal (M. Nádasi, 2011) rendelkezzen. Ezen feltételek teljesülését támogatja a módszertani szakértő bevonása, aki az oktatásfejlesztés közvetlen felelőse. 


\section{Üdv a fedélzeten}

Belépő oktatóink számára kínált programunk az Üdv a fedélzeten nevet viseli, egyelőre önkéntes alapon müködik. Minden félév elején megkeressük a négy kar frissen belépő oktatóit, és felajánljuk nekik a lehetőséget, hogy csatlakozzanak a programhoz.

A program felépítését az 1. ábrán láthatjuk (az őszi félévre vonatkozólag):

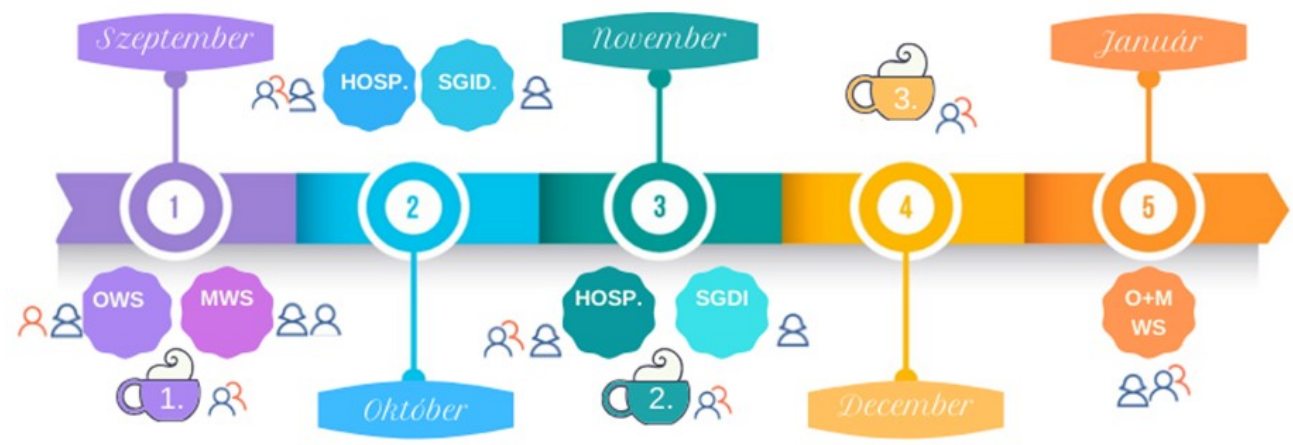

1. ábra: A Budapesti Gazdasági Egyetem belépő oktatók számára összeállított programja, az „Üdv a fedélzeten" őszi féléves szerkezete. Jelmagyarázat: OWS: Oktatói workshop; MWS: Mentori workshop; O+MWS: Oktatói és mentori közös workshop; HOSP.: óralátogatással egybekötött konzultáció a mentoráltakkal és OMK-val közösen; SGID: OMK csoportos párbeszéd a diákokkal (20-30 perc) a tárgy oktatásával kapcsolatban; Kávé: rövid kávé/ebédszünet keretében mentori egyeztetés a mentorálttal az oktatási és értékelési feladatokkal, haladással stb. kapcsolatban; 8 OMK; $8_{\text {Mentor; }} R_{\text {Mentorált }}$

A program felöleli a teljes félévet. Egy egész napos workshoppal nyitunk a szorgalmi időszak megkezdése előtt: itt szó van többek között az oktatói szerepről, hogy mitől válik valaki jó tanárrá, a kurzustervezésről, az értékelésről és a hallgatókkal való kommunikációról is. Célunk, hogy ezzel a kezdő alkalommal kapcsolatot is építsünk a kollégák között, és megismertessük velük az Oktatásmódszertani Központ funkcióit, szolgáltatásait is. A workshop vezetése során periodikusan beiktatunk metareflexiós pontokat, amik során kitérünk az adott feladat módszertani céljára, és arra, hogy ez hogyan, milyen helyzetben alkalmazható a tanítás során, ezzel példát is mutatva a tanításra és a módszertani tudatosságra. Saját belső felületünkön további módszertani segédanyagokat is rendelkezésükre bocsátunk, ami segít eligazodni a módszerekben és a hozzájuk használható eszközökben. Az oktatói szerepek alapján a workshop során támogatást adunk a pedagógiai tervezéshez, megismertetjük a tanulási eredmény alapú 
megközelítést (Farkas, 2017), a backward designt és a Bloom-féle taxonómiát (Marzano \& Kendall, 2007). Ezen kívül értelmezzük a formatív értékelés elemeit, majd együtt készítünk hallgatóbarát sillabuszt. Kitérünk az óratervezés menetére is, helyzetgyakorlatok keretében megvizsgáljuk, hogy milyen kommunikációs helyzetekbe kerülhetnek hallgatókkal, és azokat hogyan tudják megoldani. A workshopon, az együtt töltött idő végén mérjük fel, hogy kik azok az oktatók, akik szeretnének a teljes programban részt venni: nekik keresünk mentort. Emellett kézhez kapják Fedélzeti iránytű elnevezésű kiadványunkat is.

A Fedélzeti iránytűben összegyűjtöttük azokat a praktikus információkat, amelyekre az oktatóknak munkájuk során szükségük lehet egyetemünkön, olyan apróságoktól, hogy hol tudnak parkolni, ebédelni, kulcsot felvenni, olyan létfontosságúakig, hogy milyen belső dokumentumok szabályozzák a munkájukat. Kiemeltük az egyetem belső szabályozási dokumentumaiból, a Hallgatói követelményrendszerből, a Szervezeti és működési rendből azokat a részeket, amelyek a tanév során fontosak lehetnek számukra a tanítás szempontjából. Törekedtünk rá, hogy ezeket a információkat könnyen áttekinthetővé tegyük, ezért táblázatos formában vagy grafikusan jelenítettünk meg. A Fedélzeti iránytű nem tartalmaz absztrakt, elméleti ismereteket, hiszen erre a célra külön online felületünk van, hanem csak olyan egyetemspecifikus, praktikus információkat, amelyek módszertani és technikai szempontból fontosak, ilyen például az a gondolattérkép (2. ábra), amelyben összegyüjtöttük, hogy milyen oktatási módszerhez milyen szoftvert ajánlunk, ezekből mire van egyetemünknek előfizetése, vagy hogy milyen problémával melyik szervezeti egységhez fordulhatnak. Saját összeállításban készült egy ajánlás az első órára való készüléshez, illetve készítettünk egy idővonalat is, amelyen jól látszik, hogy a félév során mikor mire kell figyelnie az oktatónak, milyen teendői lesznek, amikre fel kell készülnie. A kiadványt egy szlengszótár zárja, amelyben az intézményben gyakran használt belső rövidítések, kifejezések szerepelnek. 


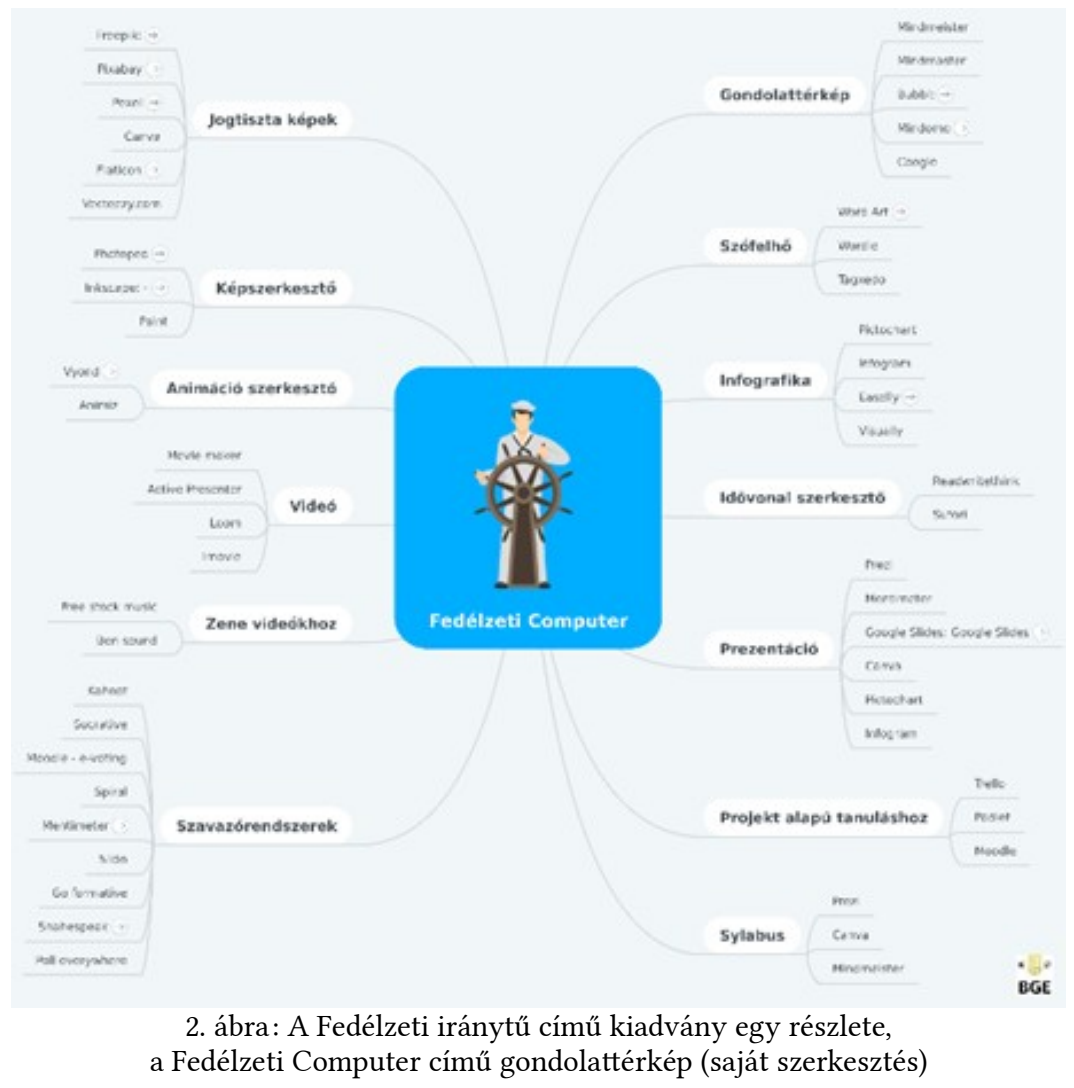

Célunk volt, hogy egy olyan kézikönyvet adjunk a belépők kezébe, ami könynyen, gyorsan fellapozható, szeretheto „kisokos”.

Az új belépő oktatók motiváltsága és érdeklődése már az első félévben felülmúlta előzetes várakozásainkat. A program indulásakor a belépő oktatóknak szervezett workshop 20 fős résztvevői létszámából hét fő rögtön jelentkezett is a teljes mentorprogramba. A mentorálásban részt vevők, öt női és két férfi kolléga közül egy kollégánk betegség miatt sajnos a program elején lemorzsolódott, őt remélhetőleg a következő tanévi programban tudjuk majd felkészíteni. Így hat fővel vezettük végig a mentorprogram folyamatát, akik közül öt fó a Pénzügyi és Számviteli Kar és egy fő a Kereskedelemi, Vendéglátóipari és Idegenforgalmi Kar munkatársa. Mindannyian különböző tantárgyat tanítottak (Vállalati gazdaságtan, Vállalkozástan, Projektmenedzsment, Karrierépítés, Bevezetés a számvitelbe, Közösségfejlesztés és -szervezés) szemináriumi keretben 25-40 fő hallgatói részvételével. 
A belépők mellé rendelt szakmai mentorok kiválasztása a dékánok, illetve a tanszékvezetők segítségével történt: ők javasoltak olyan, a belépő oktató tanszékéhez tartozó tapasztalt kollégát, akinek példaértékű a tanítása. A kiválasztott mentorok legalább 3-5 éve dolgoztak foállású munkatársként a BGE-n, és a mentoráltak tantárgyainak oktatásában közvetlen tapasztalattal rendelkeztek. Érdekes, hogy várakozásainkkal ellentétben a legtöbb mentor nem az 51-60 éves korosztályból került ki (mindössze egy fő), hanem a fiatalabb kollégák közül.

A mentorok intézményi finanszírozásból, jelképes díjazás ellenében vállalták, hogy részt vesznek egy mentori képzésen, kétszer meglátogatják mentoráltjuk óráját (egy oktatásfejlesztővel együtt), és ezen kívül még háromszor informális keretek közt megkeresik a a mentoráltat.

Az óralátogatások nagyon fontos pillérei a programnak. Ettől félnek leginkább az oktatók, de ebből is tanulnak a legtöbbet - tapasztalataink szerint utólag ezt tartják a legértékesebbnek is. Az első óralátogatásra a szorgalmi időszak első harmadánál kerül sor, mert ekkorra már túl van az oktató a legelső órák bizonytalanságain, de még marad annyi idő, hogy a megfigyeltek alapján változtasson, és ezeket a változásokat a második óralátogatás során (a félév végén) követjük. Az óralátogatást megelőzően konzultálunk az oktatóval, hogy van-e valami kérdése, valami, amire szeretné, hogy különösen figyeljünk, vagy megkérdezzünk a hallgatóitól.

Az óralátogatás során a szakmai és a módszertani lektor egy óralátogatási sablonban azonos szempontrendszer alapján értékeli az oktatót. A főbb szempontok a következők: mennyire tartja szem előtt az oktató az óra során a tanulási célokat, ezt hogyan kommunikálja a hallgatók felé, illetve milyen módon ad visszajelzést a hallgatóknak. A mentorok emellett figyelték a kolléga oktatási stratégiáját, prezentációs képességeit, az óra légkörét, hogy mik voltak a tanítás leghatékonyabb elemei és mik a potenciális fejlesztendő területek.

Az óra vége előtt kb. 15 perccel az oktató távozik, és az oktatásfejlesztő ún. kiscsoportos oktatási diagnosztikát (Small Group Instructional Dialogue: McKeachie \& Svinicki, 2013) végez a hallgatókkal. Ennek során a hallgatók előbb 3-4 fős csoportokban, előre megadott kérdések alapján reflektálnak a tanulási élményükre. Pontokba szedik az erősségeket és fejlesztő javaslataikat, amelyeket pár mondatban meg is indokolhatnak írásban. A második óralátogatás alkalmával az SGID felmérés keretében arra fókuszálunk, hogy miben fejlődtek a félév során a hallgatók, illetve az oktató. A felmérő lap végén feleletválasztós kérdés formájában kér- 
dezzük meg a csoportokat, hogy lassúnak, megfelelőnek vagy túl gyorsnak ítélték-e az óra menetét. A protokoll nagycsoportos konszenzusfelméréssel végződik, aminek során a hallgatói csoportok kiemelhetnek egy-egy fontosnak érzett pontot. Kézfeltételes szavazással jelzik, hogy mennyire értenek egyet az állítással, így erre vonatkozóan hozzávetőleges eredményeink vannak. A kitöltött adatlapokat az óra végén az oktatásfejlesztő összegyüjti.

A kitöltők száma tárgyanként eltérő, az első félévben 10-40 fő között mozgott. A hallgatók többször jelezték az SGID során, hogy nagyra értékelik, hogy az oktatójuk fejlődni akar, és hogy az ő véleményükre is támaszkodik ebben. Visszajelzéseik többsége ennek megfelelően konstruktív, támogató volt, annak ellenére, hogy a folyamat anonim volt, és az SGID folyamat elején tájékoztattuk a hallgatókat, hogy a véleményüket az oktatók csak összegezve, átfogalmazva fogják megkapni.

Tapasztalatunk szerint a hallgatói visszajelzések nagyrésze rövid, tömör volt, kevés kifejtéssel, így az utána következő megbeszélő kör nagyban segített értelmezni a leírtakat. Íme néhány példa a hallgatók visszajelzéseiből:

Erősségek:

„Kikéri a véleményünket, és nincs jó vagy rossz válasz, és ezt érezzük is.” Javaslatok:

\section{„Kicsit lehet magabiztosabb.”}

Az óralátogatás végeztével az oktatásfejlesztő két jelentést készít az oktatónak: egyet az SGID eredményéről és egyet a saját megfigyeléseiről és javaslatairól. A jelentéseket az óralátogatást követő megbeszélés előtt elküldjük az oktatónak, hogy legyen ideje átolvasni, és kérdéseket megfogalmazni a tartalommal kapcsolatban.

Az óralátogatásról készült jelentések és a megbeszélés a program legfontosabb építőkövei. Ez az a pont az oktatók fejlődésében, amikor az ún. EPIC-fázisokon a legnagyobb haladást lehet velük elérni. Az EPIC-modell (Aragón et al., 2017) írja le azt a folyamatot, amelynek során az oktató megismer és kipróbál egy számára új, tanulóközpontú módszert (például a csoportmunkát, a gamifikációt stb.), meggyőződik annak hasznosságáról, implementálja, majd hosszú távon elköteleződik mellette. Az óralátogatáshoz kapcsolódóan két dolog történik: először az oktató konkrét, személyre szabott tanácsokat kap olyan további módszerek használatára, amelyekkel az adott tárgyat még jobban tudná tanítani. Ezzel gyorsíthatjuk azt a folyamatot, hogy a megfelelő módszerről hallva meggyőződjön annak hatásosságáról, és beépítse azt a félév további részében. 
Másodszor, a már használt jó módszerekkel kapcsolatban az oktató megerősítést kap a mentoraitól és a hallgatóktól is, és így nagyobb eséllyel köteleződik el hosszú távon is, lásd az alábbi példát (részlet egy SGID jelentésből):

Minden hallgató egyetértett abban, hogy jó érzés, hogy mindenkire odafigyelsz, és azért jössz oda a csoportokhoz, hogy segíts. Örülnek a visszacsatolásnak és annak, hogy a csoportvisszajelzéseket beépíted az óra menetébe. Abban is egyetértettek, hogy kellemes légkört teremtesz órán. A következőket emelték ki a hallgatók mint erősségeidet:

- Hallgatóbarát.

- Próbál a diákok nyelvén beszélni, érthetóen magyaráz.

- fó feladatokat ad, megmozgat minket, gyakorlati tudást szerezhetünk az órán.

- Együtt beszéljük meg a dolgokat, mindenki elmondhatja a véleményét, ad a véleményünkre.

- Konkrét projekteken dolgozhatunk.

A második óralátogatás célja a változtatások megfigyelése, és hatásuk lemérése a hallgatók segítségével, egy ismételt SGID alkalmazásával. A második SGID felmérés során módosított kérdéssorral dolgozunk, hiszen itt arra vagyunk kíváncsiak, miben látnak változást a hallgatók. Ezt ismét a szokásos két jelentés követi egy megbeszéléssel, ahol megbeszéljük az oktatóval a félév tanulságait, és tervet készítünk a jövőre nézve.

A programot egy közös mentor-mentorált esemény zárja, amelyen a team minden tagja részt vesz. Ennek során összefoglaljuk a félév tanulságait mind a mentorok, mind a mentoráltak részéről, megnézzük, ki miben fejlődött, és megünnepeljük a sikereket.

\section{Tanulságok, kihívások és jövőbeni tervek}

A program sikere minden várakozásunkat felülmúlta. Az első vizsgált csoport résztvevői mindannyian lelkesedéssel és hálával nyilatkoztak a programban való részvételükről, különösen az első jelentések kézhezvétele után.

Érdekes tapasztalat volt az első vizsgált csoportban olyan belépőket is mentorálni, akik nem tipikus fiatal pályakezdő oktatók voltak, mert például másutt már tanítottak, vagy hosszú, sikeres versenyszférabeli karrier után döntöttek úgy, hogy tanításra adják a fejüket. Az ilyen esetekben válik különösen fontossá a személyes odafigyelés, hiszen a sztereotipikus pályakezdőkre kalibrált tréningek 
ezeknek az oktatóknak az igényeivel csak részleges átfedést mutatnak. Izgalmas kihívás volt ezekben az esetekben megfelelő mentort is találni, és akadt is olyan esetünk, ahol a mentorált jóval több szakmai tapasztalattal bírt, mint mentora, akinek viszont több tanítási tapasztalata volt.

Az egyik legnagyobb kihívás az óralátogatásokkal kapcsolatos félelmek eloszlatása, amelyekkel kapcsolatos szorongás csak a folyamat végén, a hallgatói jelentések kézhezvétele után csökken.

A másik nagy kihívás a program résztvevőinek rekrutálása: nehézkes annak követése, hogy az adott félévben melyik tanszékre érkezik új kolléga. Ennek részben az az oka, hogy az adott félévben belépőkről az információt sok helyről kell összegyüjteni, nincs kialakult szervezeti útja ennek az információnak.

Tekintettel a program sikerére, a közeljövőben várhatóan kapacitásproblémákkal is küzdeni fogunk. Az első csoport hat résztvevőjének támogatását három oktatásfejlesztő segítségével zökkenőmentesen meg tudtuk oldani - ám az egy félévben belépő oktatók száma ennek többszöröse is lehet. Ha azonban a jelentkezők száma a következő félévekben megtöbbszöröződik, jelenlegi kollégáinkkal már nem fogjuk tudni kielégíteni ezt az igényt.

Az eredményesség kvantifikálásának egyik módja lehet a programban részt vevő és részt nem vevő kollégák csoportjainak szisztematikus összehasonlítása, vagy a programban részt vevő kollégák és régebbi (a programunk előtti) belépő oktatók összehasonlítása, például a hallgatói értékeléseket felhasználva.

A jövőre vonatkozó terveink legfontosabb eleme a program hatékonyságának és eredményességének sokoldalú és részletes mérése. Az adatokat jelenleg saját megfigyeléseinkből, illetve két leíró, önbevallásos forrásból gyűjtjük: a program végén mind a mentorok, mind a mentoráltak leadnak egy részletes önreflexiót és egy fejlődési naplót, amiből kvalitatív következtetéseket le tudunk vonni, de kvantifikálni egyelőre nem tudjuk az eredményeinket. További mérendő terület a mentorok mint oktatók fejlődése: számos informális megjegyzésből következtethetünk arra, hogy a belépő kollégák megfigyelése a mentorok számára nagyon tanulságos saját oktatói gyakorlatuk szempontjából is.

Egységünk célja, hogy a hallgatók minél hatékonyabban és élvezetesebben tanuljanak a BGE-n töltött éveik során, amihez olyan oktatói teamre van szükség, akik rutinosan, magabiztosan használnak tanulóközpontú, hatékony, aktív oktatási módszereket. A program további hozadéka, hogy a résztvevők a kezdetektől elsajátítják a fejlődési szemléletet (Dweck, 2015), igényük lesz arra, hogy folyama- 
tosan fejlődjenek, a tanulásról és a tanításról kollégáikkal, az oktatásfejlesztőkkel és a hallgatókkal együttmúködésben gondolkozzanak - elindítva ezzel a kultúraváltást az egyetemen.

\section{Irodalom}

Aragón, O. R., Dovidio, J. F., \& Graham, M. J. (2017). Colorblind and multicultural ideologies are associated with faculty adoption of inclusive teaching practices. Journal of Diversity in Higher Education, 10(3), 201-205.

DOI: $10.1037 /$ dhe 0000026

Balázsiné Farkas, K. (2017). A munkaerőpiac pályakezdő számviteli szakemberekkel szemben támasztott kompetencia követelménye. Doktori disszertáció.

https://doktori.hu/index.php?menuid=193\&lang $=$ HU\&vid=17 512 (2020. 07. 29.)

Bell, C. R. (2002). Managers as Mentors. 2. kiadás, Berrettkoehler.

Copenhagen Business School (2018). Assistant Professor Programme. https://www.cbs.dk/en/research/cbs-research-profile/assistant-professorprogramme (2020. 01. 10.)

Dweck. C. S. (2015). Szemléletváltás - A siker új pszichológiája. HVG Kiadó.

Farkas, É. (2017). Tanulási eredmény alapú tanterv-és tantárgyfejlesztés a felsőoktatásban. Szegedi Egyetemi Kiadó Juhász Gyula Felsőoktatási Kiadó.

Fessler, R. (1991). The Teacher Career Cycle: Understanding and Guiding the Professional Development of Teachers/Ralph Fessler, Judith C. Christensen.

Füzi, B. \& Suplicz, S. (2016). A mentorálás pedagógiája. Szakmai Pedagógusképzés Sorozat 18. kötet, Typotop.

Hénard, F. \& Roseveare, D. (2012). Fostering Quality Teaching in Higher Education: Policies and Practices. IMHE, OECD

Huba, M. E., \& Freed, J. E. (2000). Learner-centered assessment on college campuses: Shifting the focus from teaching to learning. Allyn \& Bacon.

Kálmán, O. (2019). A felsőoktatás oktatóinak szakmai fejlődése: az oktatói identitás alakulása és a tanulás módjai. Neveléstudomány: Oktatás - Kutatás - Innováció, 7(1), 74-97. DOI: 10.21549/NTNY.25.2019.1.6

Katz, L. G. (1972). Developmental stages of preschool teachers. The Elementary School fournal, 73(1), 50-54. DOI: 10.1086/460 731

Kram, K. (1985), Mentoring at Work. Foresman Scott.

Magyarország Digitális Oktatási Stratégiája (2016). https://www.kormany.hu/download/0/cc/d0000/MDO.pdf (2020. 01. 10.) 
Pedagógusképzés • 19(47), 2020/1-2.

M. Nádasi, M. (2010). A projektoktatás elmélete és gyakorlata. Magyar Tehetségsegítő Szervezetek Szövetsége.

Marzano, R. J. \& Kendall, J. S. (2007). The New Taxonomy of Educational Objectives. II. kiadás.Corwin Press.

McKeachie, W. \& Svinicki, M. (2013). McKeachie's teaching tips. Cengage Learning (pp. 334-335). Cengage Learning, Inc.

Russel, J. E. A. \& Adams, D. M. (1997). The Changing Nature of Mentoring in Organizations: an Introduction to the Special Issue on Mentoring in Organizations. Journal of Vocational Behavior, 51(1), 1-14. DOI: 10.1006/jvbe.1997.1602

Seemiller, C., \& Grace, M. (2016). Generation $Z$ goes to college. John Wiley \& Sons.

VSNU (2018). Professionalisation of university lecturers. The UTQ and beyond. https://www.vsnu.nl/files/documenten/Professionalisation\%20of\%20university \%20lecturers.pdf (2020. 01. 10.)

Yonge, O. \& Davidson, S. (2017). "Promoting Scholarship and Faculty Development through Faculty Learning Communities." Quality Advancement in Nursing Education - Avancées en formation infirmière. 3(2).

DOI: $10.17483 / 2368-6669.1120$

\section{Welcome Aboard: Mentoring entering faculty at the Budapest Business School}

In reaction to the latest trends in higher education we created a comprehensive developmental program for entering faculty at the Budapest Business School. The pillar of this program titled Welcome Aboard is the mentee-disciplinary mentorpedagogical mentor triad that works in unison for a semester. The framework was designed using the EPIC-model of innovation, the developmental model of faculty and the mentoring literature; components of the program were inspired by several faculty development programs from around the world. We describe the background and structure of Welcome Aboard first along with lessons learned, the use these to outline future plans and to put forth recommendations for Hungarian higher education.

Keywords: Higher education, mentoring, SGID, education development, socialization 